\title{
Issues about Innovation of Present Theory of Accounting
}

\author{
Enzhu Li \\ School of Accounting, Shandong University of Finance, Ji'nan 250014, China \\ School of Management, China University of Mining \& Technology, Xuzhou 221116, China \\ E-mail: lez11513@163.com
}

\begin{abstract}
With the method of theoretical analysis, this thesis, systematically analyzed the limitations of the present theory of accounting in recycle economy and the reasons for that, analyzed the characteristics of accounting in recycle economy, and, according to the internal demand of recycle economy, put forward brand new development orientation of theory of accounting that would be suitable for recycle economy development. It specially discussed four suggestions, including constructing brand new accounting information disclosure model in recycle economy, bringing resource assets into accounting system, introducing new accounting method, and improving the control theory for accounting cost (including safety cost). This thesis will be a reference for the development of theory of accounting in Chinese recycle economy.
\end{abstract}

Keywords: Recycle economy, Theory of accounting, Limitation, Safety cost

World economy is developing at great speed, every country is being confronted with the problems of resource exhaustion, environmental pollution and ecological damage, so it is urgent for every country to develop recycle economy (Ji, 2004), and China has made strategic programming for the development of recycle economy. From the viewpoint of accounting, traditional theories of accounting are based on linear economics, so traditional accounting takes enterprise as a individual system, it only cares about the operating status and financial achievement of the enterprise itself, but neglects the influence of business operation on natural environment and society. The rapid development of recycle economy in western developed countries puts forward new challenges for the present accounting of theory, this paper makes a brief discussion about the influence of recycle economy on the present theory of accounting.

\section{The characteristic of accounting in recycle economy}

Compared with the traditional accounting, accounting in recycle economy has the following characteristics:

\subsection{The main users of accounting information are different}

The main users of traditional accounting information are the investors and creditors of enterprise; while the main users of accounting information in recycle economy is the relating departments of government, especially the management department of environmental protection and tax inspection department. According to the accounting information provided by enterprises, departments of government will understand enterprise's investment in treatment of environmental pollution and the return of renewable resources; accordingly, they can make macro policy and assess, punish or encourage enterprises according to the information. In addition, the external investors of enterprise have to know about the enterprise's situation of fulfilling environmental protection responsibility, and the situation of getting direct return and tax advantage from the transformation of contaminations into renewable resources in accordance with the recycle economy information, so as to estimate the development prospect of enterprise and make decision about the investment behavior.

\subsection{The accounting entities are different}

Enterprise should build up the concept of adapting to the environment of recycle economy if they want to realize longtime existence and stable development in the new economic environment, the following are reasons.

Firstly, social environment is the system basis for the existence and development of enterprise, while the natural environment is the material basis. Enterprises should adapt themselves to social environment as much as possible, they should look for best investment environment, financing environment, market environment and policy environment so as to realize longtime existence and stable development. From the angle of development cycle, the existence and development of enterprise need the resources from natural environment, and enterprise will discharge rubbish to the environment, if there is no durable and stable natural environment as material basis, it is impossible for enterprise to realize longtime existence and stable development.

Secondly, the disclosure of information of developing recycle economy, especially the information about resource and environment, will make enterprise that performs good environmental behavior get good image in public and community, and get good market returns in capital market and product market; also, it will make the enterprise that 
performs bad environmental behavior strengthen pollution control and improve environmental behavior (Wang, 2000; Milne, 1999). Effective information disclosure will reduce transaction cost and improve the effective allocation of resource; the effect of bestirring enterprise's environmental protection behavior will be more obvious if the environmental information is disclosed to a greater extent.

\subsection{The accounting information disclosure forms are different}

The main form of traditional accounting information disclosure is financial statements, together with annotations to financial statements and text notes. While in recycle economy, there is much non quantitative information; accordingly more practical things are used to disclose the environmental information of enterprises, and more annotations and text notes are needed. The format and content of financial statements should be reformed, financial statements and reports that reflect the information of recycle economy should be added, for example, table of return from renewable resources, report of resource environment responsibility.

\subsection{The accounting methods are different}

In traditional accounting, monetary measure is used, but in recycle economy accounting, both monetary measure and non monetary measure should be used. Because resource asset comes from the longtime accumulation of nature, there is no human labor in it, it is impossible to make sure its value according to the method of social labor productivity, hence, its value should be determined by the method of indirect calculation. Further more, the regeneration period of natural resources are different, there is no uniform standard. The combination of monetary measure and non monetary measure will provide more integral and accurate information.

\subsection{The preconditions of accounting theory and practice are different}

Sustainable development is the precondition of theory and practice of accounting in recycle economy. Accounting in recycle economy should check and supervise the economic activity of enterprise, reflect the energy exchange and value transfer between enterprise operation and environment on the basis of sustainable development of human society. The theory of recycle economy is the precondition and basis of the establishment and development of environmental accounting. The accounting in recycle economy is based on the long-term coexistence and mutual benefit between enterprise and environment; it attaches importance to the sustaining operation of enterprise under the precondition of good circulation of resources. Without the sustainable development of natural environment, the operation of enterprise will be difficult, and there will be no necessary and basis for the existence of accounting.

Hence, in recycle economy, accounting should take on the task of calculating the input and output of enterprises in the new economic conditions, confirming the responsibility of resource usage, calculating the relating expense, revenue and loss to get renewable resources, further more, it should provide real and credible accounting information about the resource utilization efficiency for enterprise to realize their objectives.

\section{The limitations of the present theory of accounting in recycle economy}

The objective of the present accounting is to check and supervise the linear economic activity, and provide financial information for management and examine the managerial responsibility, so as to achieve maximal economic benefit. The limitations of the present theory of accounting in recycle economy development are as follows:

\subsection{The present theory of accounting pays little attention to the utilization of renewable resources}

The problems of recycle economy are not studied in the present theory of accounting, specifically, the accounting information of business activity in recycle economy is not disclosed thoroughly, the accounting cycle is not integral, the resource assets, renewable resource assets, relating responsibility and expense are not calculated and checked fully, the benefit or loss of enterprise are not confirmed, and the benefit brought by renewable resources are not calculated and checked thoroughly.

\subsection{The present theory of accounting doesn't take enterprise as an economic body that coexists with the natural environment}

The present financial accounting process only covers the linear process from getting resources from environment to the realization of product and economic benefit; it doesn't realize that the economic operation is closely related with natural environment, it neglects the influence of resource and environment on enterprise and the influence of enterprise on natural environment, it also neglects the material complement process of environment itself and enterprise's responsibility to complement the natural environment. Specifically, the present accounting doesn't confirm natural resources as assets, doesn't confirm enterprise's social benefit responsibility, safety production responsibility and environmental protection responsibility as debt, doesn't confirm resource as rights and interests of owner, and doesn't specifically reflect the income, expense and profit of renewable resources in resource circulation process. 


\subsection{Recycle economy information is not included in the present accounting information disclosure}

Some relating recycle economy information cannot be disclosed because some technical problems in the present accounting information disclosure cannot be solved thoroughly, Such as the disclosure scope of enterprise resources and renewable resources, the establishment of technical criteria and style, the relationship between publicity and business secret, the accounting of cost and risk of resource information disclosure, the inspection of information disclosure behavior, the criteria for audit, counterclaim and punishment for the loss caused by distortion of environmental information disclosure.

\section{The developmental orientation of the present theory of accounting}

The present theory of accounting is based on the linear economy and serves the industrial economy. In recycle economy, lots of new situation and problems will come up, so it is urgent to make innovation in the theory of accounting and expand the research area in the following aspects:

\subsection{The construction of accounting information disclosure model in recycle economy}

Recycle economy is completely different from the traditional economy, it changes the traditional economic developmental model of open material cycle, i.e. "resource-product-waste" to the new developmental model of closing material cycle, i.e. "resource-product-renewable resource", so as to realize "low exploitation, full utilization and low discharge", maximally utilize the material and energy of the system and improve the resource utilization ratio, maximally reduce the discharge of contamination, improve the quality and benefit of economic operation and protect ecological environment. The era of recycle economy make higher demand on accounting information, the information should be real, accurate, timely, convenient, applicable and practical, it should not only reflect the actual situation, but also predict the future. Accounting should not only provide internal information, but also provide relating external information; there should be monetary information, and non monetary information, which are the report forms of "products" of accounting. The present single pattern should be changed, and the content of renewable resources should be disclosed in the report form system, so as to meet the need of recycle economy.

The accounting information in recycle economy is the information about the operation behavior and environmental work of enterprise, and their influence on finance. The forms of accounting information are diversified; there are qualitative information and quantitative information, monetary information and non monetary information, such as things and technology. Hence, the following principles should be paid attention to when choosing the accounting information disclosure mode in recycle economy: firstly, the least amount of relating information that should be disclosed will be prescribed by system; secondly, the mechanism for enterprise to disclose information voluntarily should be established; thirdly, the resource accounting information, practical thing information and the financial information should be combined, on the one hand, the influence of resource and environmental problem on finance can be revealed by financial report form, annotations to report form, and financial situation report; on the other hand, the utilization status of resource and renewable resource can be provided by special "liability report about resource environment".

\subsection{Resource assets should be brought into accounting system}

Recycle economy demand the sustainable development of society and economy, so the resources should be utilized effectively. In a long period of time, the accounting of resource is not good enough, the Enterpise Accounting Criteria No.27- Oil and Natural Gas Exploitation: the Mining of Oil and Gas is a good example of accounting of resource assets, but the accounting of other resources has not been started. From the angle of recycle economy, it is urgent to calculate and utilize the resource asset well. The modern economics thinks that things that will bring benefit for people are assets, natural resources are asset, no matter they are natural or processed by human, exhaustible or renewable, accordingly, natural resources have property right and value, so it is necessary to calculate and control the natural resource. The accounting of resources should be done macroscopically and microscopically, so there must be microeconomic organization, such as enterprises, to take part in the accounting in order to realize the real meaning of accounting. Besides, in order to improve the utilization efficiency of resources, standard to control the utilization of resources should be established; accounting control system for the cost of resource should be established, the utilization of resources and the production, product, service should be combined to improve the utilization efficiency of resources, periodical analysis and evaluation system should be established to maximize the utilization efficiency of resources; both practical things and money should be used in accounting system to record the utilization situation of resources, the cost of resources should be displayed independently; the amount of consumed resources and the cost should be paid attention to in decision-making of long-term production, operation and investment, the price trend of the future resources should be estimated effectively; clean energy and renewable resources should be used, effective measures should be taken to facilitate the cycle utilization of resources and energy. In that way, the objective of developing economy with the least resources and protecting environment with 
the least cost will be realized.

\subsection{Investigate and introduce new accounting methods}

In recycle economy, the center of accounting should be changed from resource consumption to calculation and reuse of resources, and the biggest obstacle for that is the accounting problem. The traditional accounting methods can not accommodate the development of recycle economy, so it is necessary to reform in the accounting methods. The social substances are multiple, if only one accounting method is used, accounting will be bogged down. Hence, multiple accounting methods should be introduced into accounting system and these methods will be used in different situations.

\subsection{Improve the accounting cost control theory}

Every step of the accounting cost control theory should be related to the recycle of resources. The daily production and operation of enterprise correlate with lots of problems of resource consumption, so resource should be taken into consideration in the management of working capital. Special resource cost control system should be established to realize the high-efficient and circular utilization of resources. The overall budget of enterprise and the liability accounting of its execution, and the difference analysis system should take resource problem into consideration and improve the resource utilization efficiency by pricing resources, establishing energy-saving standard and carrying out energy-saving management. With the development of computer technology, intellective technology for recycle of resources will be introduced into the accounting information system, various kinds of expert systems will provide help for accountants and managers, such as resource cost analysis and control, energy-saving and consumption-reducing of product etc. Besides, the resource consumed in preventing production accident should be listed as safety cost, which will be propitious to the sustainable development of recycle economy.

\section{Conclusion}

The present theory of accounting is the product of linear economy, the objective, method, management system and criteria system of the present theory of accounting cannot meet the need of recycle economy development. The development of theory of accounting is an all-round systematic engineering; the component of theory of accounting will be endowed with new meaning according to the requirement of recycle economy. We should use the international experience in developing recycle economy as reference, according to the practical situation and legislation condition of China, investigate the development model in recycle economy and feasible theory of accounting, and promote the establishment of accounting system in recycle economy by using appropriate law and regulations.

\section{References}

Ji kunsen. (2004). Principles and practices of circular economy. Anhui Science and Technology Press.

Wang Hua. (2000). Information approach to industiral pollution control and its application in China. China environmental science( 3 ).

Milne M.J. and Adler R.W. (1999). Exploring the reliability of social and environmental disclosures content analysis. Accounting, Auditing and Accountability Journal. (2): 237-256. 